\title{
Teachers Challenges In The Using Of Blood Learning Media In Kids Garden
}

\author{
Viona Olyvia, Asdi Wirman
}

Received: 13062021 / Accepted: 03062021 / Published online: 30062021

(C) 2021 Association of Indonesian Islamic Early Childhood Education Study Program

\begin{abstract}
Abstrak Penelitian ini bertujuan untuk mengungkapkan tantangan guru dalam penggunaan media pembelajaran daring dan untuk menemukan solusi yang dapat diambil oleh guru. Pada pandemic saat ini guru dituntut mampu menguasai teknologi, agar guru dapat memanfaatkan berbagai media daring dalam pembelajaran. Saat ini sangat banyak guru PAUD kebingungan dalam memanfaatkan media daring berbasis teknologi. Akhirnya dengan cara sederhana guru memberikan tugas tertulis melalui grup whatsApp kepada orang tua untuk dikerjakan oleh anak. Aktivitas yang baru ini mengharuskan guru memiliki kompetensi dalam mengoperasikan teknologi untuk merancang dan menggunakan media pembelajaran yang tepat pada anak. Guru dituntut cepat beradaptasi dengan teknologi agar guru mampu menggunakan beragam aplikasi untuk menunjang pembelajaran daring. Metode penelitian yang digunakan adalah studi literatur dimana teknik pengumpulan datanya melalui pengolahan dan menganalisis berbagai sumber atau referensi jurnal ilmiah dan buku sehubungan dengan masalah yang akan diteliti. Analisis data menghubungkan masalah dengan teori yang terkandung dalam jurnal ilmiah atau buku-buku yang sesuai. Hasil penelitian ini menemukan bahwa dalam penggunaan media pembelajaran daring, terdapat beberapa tantangan guru seperti lemahnya kompetensi guru dalam menguasai teknologi, kurangnya sarana dan prasarana dalam memanfaatkan berbagai media pembelajaran daring dan terbatasnya jaringan internet dalam mengkover media pembelajaran daring lainnya. Solusi yang dapat diambil guru ialah dengan melakukan berbagai pelatihan, webinar ataupun workshop. Guru juga dapat memanfaatkan berbagai platform pelatihan yang disediakan kemendikbud secara gratis maupun berbayar.
\end{abstract}

Kata Kunci: Tantangan Guru, Media Pembelajaran Daring, Anak Usia Dini

\begin{abstract}
This study aims to reveal the challenges of teachers in using online learning media and to find solutions that can be taken by teachers. In the current pandemic, teachers are required to be able to master technology, so that teachers can take advantage of various online media in learning. Currently, many PAUD teachers are confused about utilizing technology-based online media. Finally, in a simple way, the teacher gives written assignments through the WhatsApp group for parents to work on by children. This new activity requires teachers to have competence in operating technology to design and use appropriate learning media for children. Teachers are required to quickly adapt to technology so that teachers are able to use various applications to support online learning at. The research method used is a literature study where the data collection technique is through processing and analyzing various sources or references to scientific journals and books whose relevance with the problem to be studied. Data analysis relates problems to theories contained in scientific journals or appropriate books. The results of this study found that in the use of online learning media, there were several challenges for teachers such as the weak competence of teachers in mastering technology, the lack of facilities and infrastructure in utilizing various online learning media and the limited internet network in
\end{abstract}


covering other online learning media. The solution that teachers can take is to conduct various trainings, webinars or workshops. Teachers can also take advantage of various training platforms provided by the Ministry of Education and Culture, free or paid.

\section{Keywords: Teacher Challenges, Online Leraning Media, Early Childhood}

\section{Pendahuluan}

Pendidikan anak usia dini (PAUD) ialah suatu upaya pembinaan yang ditujukan pada anak sejak lahir sampai usia 6 tahun. Anak sebagai generasi penerus sangat perlu dibekali kemampuan untuk mengoptimalkan seluruh aspek dan potensi yang dimilikinya. Adapun aspek perkembangan anak yang meliputi aspek perkembangan kognitif, bahasa, social, emosional, nilai-nilai agama dan moral, serta fisik dan motorik. PAUD merupakan peletak dasar pertama dan utama dalam mengembangkan segala aspek perkembangan pada anak (Mulyasa, 2012). PAUD dini itu ialah pembinaan yang ditujukan kepada anak sejak lahir sampai anak berusia enam tahun dengan pemberian stimulasi pendidikan untuk membantu pertumbuhan dan perkembangan anak dalam memasuki pendidikan lebih lanjut (Yamin, 2012).

Adapun karakteristik anak usia dini yaitu egosentrik, rasa ingin tahu, unik dan kaya akan imajinasi, serta memiliki daya konsentrasi yang rendah (Suryana, 2013). Sedangkan karakteristik PAUD itu ialah mengutamakan kebutuhan anak, bermain seraya belajar, lingkungan kondusif, dan menggunakan media serta sumber belajar dan dilaksanakan secara bertahap (Suyadi, 2010). Prinsip PAUD ialah berorientasi pada kebutuhan anak dan melakukan pembelajaran melalui kegiatan bermain (Latief dkk, 2013).

Dalam pembelajaran sangat dibutuhkan guru yang professional, agar pembelajaran menyenangkan bagi anak. Guru professional harus mampu melakukan kegiatan pembelajaran secara efektif dan efesien. Pembelajaran yang efektif dilakukan pada PAUD sangat penting, karena melalui pembelajaran anak akan mendapatkan stimulasi serta dukungan untuk tumbuh dan berkembang. Oleh karena itu, anak perlu diberi rangsangan, dorongan dan dukungan berupa program kegiatan pembelajaran yang manarik, efektif serta bermakna bagi anak.

Penerapan pembelajaran untuk mencapai keenam aspek perkembangan pada anak untuk saat ini terhambat oleh pandemic COVID-19 (Hapsari dalam Wulandari, 2020). Selama pandemi, ada beberapa peraturan yang diberlakukan oleh pemerintah yaitu social distancing. Dimana social distancing ini merupakan upaya jarak jauh dan menghindari kerumunan, sehingga pada pendidikan juga diberlakukan social distancing. Oleh karena itu sistem pembelajaran berubah dari tatap muka menjadi pembelajaran jarak jauh atau pembelajaran online. Bilfaqih dan Qomarudin dalam (Ayuni, 2020) mengatakan pembelajaran daring merupakan pembelajaran yang dilakukan dalam jaringan yang dapat dilakukan dimana saja dan kapan saja. Almarzooq dalam (Ayuni, 2020) menyatakan bahwa pembelajaran daring dapat dilakukan melalui program teknologi yang baru seperti aplikasi zoom ataupun aplikasi whatsApp.

Pembelajaran daring ialah transformasi pendidikan tetap muka ke dalam bentuk digital yang tentunya memiliki peluang dan tantangan yang sangat berat serta berdampak terhadap potensi tumbuh kembang anak (Suhendro, 2020). Sistem pembelajaran daring itu ialah sistem pembelajaran tanpa tatap muka, tetapi dilakukan melalui online dengan menggunakan jaringan internet (Harnani, 2020). Khadijah dalam (Anita, 2020) pada pendidikan anak usia dini pembelajaran jarak jauh yang diterapkan ialah melalui interaksi antara guru dan orang tua dalam menyiapkan kegiatan bermain bersama anak. Dalam pembelajaran daring juga sangat dibutuhkan media pembelajaran. Media pembelajaran pun juga berubah kedalam bentuk digital, melalui aplikasi-aplikasi yang dapat menghubungkan antara guru dan anak.

Media pembelajaran daring adalah inovasi terbaru dalam pembelajaran dengan menggunakan teknologi melalui jaringan internet. Dalam kegiatan pembelajaran daring dapat menggunakan media daring seperti aplikasi whatsApp, zoom meeting, dan youtube (Nurdin, 2020). Media pembelajaran online ialah suatu proses belajar mengajar yang akan disampaikan bahan ajar kepada anak dengan menggunakan internet (Nuriansyah, 2020). Dabbagh dan 
Ritland dalam (Sebayang dkk, 2020) mengatakan media pembelajaran daring sebagai sistem belajar yang terbuka dan tersebar dengan menggunakan perangkat pendidikan melalui internet dan teknologi berbasis jaringan.

Media pembelajaran online merupakan salah satu bentuk media pembelajaran jarak jauh dengan menggunakan komputer yang dilengkapi sarana telekomunikasi internet (Putranti, 2013). Penggunaan media berbasis teknologi yaitu seperti aplikasi whatsApp, zoom, google meet, dan aplikasi lainnya yang dapat membantu dalam melaksanakan pembelajaran daring (Sudrajat, 2020). Keuntungan penggunaan media pembelajaran online ialah pembelajaran yang bersifat mandiri dan mampu meningkatkan ingatan serta lebih banyak memberikan pengalaman belajar, dengan audio, video, dan animasi dalam pembelajaran (Atsani, 2020). Dengan adanya media pembelajaran daring ini dapat memudahkan anak untuk belajar dari rumah dengan bimbingan orang tua dan mendorong penyelenggaraan pembelajaran semakin efektif.

Media pembelajaran daring merupakan salah satu komponen pembelajaran yang sangat berperan penting dalam pembelajaran, sehingga guru perlu mempelajari bagaimana menetapkan media pembelajaran yang efektif. Dalam menjalankan tugasnya dengan professional yang harus dimiliki guru yaitu kompetensi (Adlin, 2019). Mulyasa dalam (Subhi, 2020) mengatakan bahwa kompetensi guru merupakan perpaduan antara kemampuan personal, keilmuan, teknologi, social, dan spiritual yang dapat membentuk kompetensi profesi guru, sehingga mencakup penguasaan materi, pemahaman terhadap anak dan pembelajaran yang mendidik. Kusnandar dalam (Elfahmi, 2020) menjelaskan bahwa kompetensi guru itu ialah seperangkat kemampuan yang harus ada dalam diri guru agar dapat mewujudkan kinerjanya secara efektif. Salah satu kompetensi yang harus dimiliki guru yaitu kompetensi pedagogi. Dimana kompetensi pedagogic ini merupakan kompetensi khas yang membedakan guru dengan profesi lainnya serta kemampuan guru dalam mengelola pembelajaran yang mendidik (Ahmad, 2020).

Susanto dalam (Sudrajat, 2020) mengatakan kompetensi pedagogic merupakan kemmapuan guru yang berkenaan dengan penguasaan teoritis dan praktis dalam pembelajaran, seperti mengelola, merencanakan, melaksanakan dan mengevaluasi pembelajaran. Kompetensi pedagogik ialah kemampuan guru dalam mengelola aktivitas pembelajaran dan menguasai materi pembelajaran secara mendalam untuk membimbing anak (Sum dan Emilia, 2020). Pada kompetensi pedagogic telah disebutkan bahwa seorang guru harus mampu menguasai teknologi dalam pembelajaran, karena dengan memanfaatkan teknologi pada pembelajaran dapat mendukung pelaksanan tugas guru untuk mencari dan mengunduh sumber-sumber belajar (Adisel dan Prananosa, 2020).

Dalam penggunaan media pembelajaran daring sangat dibutuhkan komunikasi yang efektif, empati dan santun. Pada masa pandemic ini komunikasi antara anak menjadi kunci utama pembelajaran melalui daring (Sudrajat, 2020). Pembelajaran daring saat ini diberlakukan pemerintah, mengharuskan guru untuk mengajar dengan memanfaatkan media daring yang efektif, mudah diakses serta dipahami oleh anak (Elfahmi, 2020). Guernsey dalam (Ulfa, 2016) mengatakan bahwa teknologi menjadi media untuk mendukung pembelajaran dan digunakan sebagai sumber tambahan dalam memperluas akses anak-anak melalui konten belajar yang baru.

Pada pandemic saat ini sistem pembelajaran tatap muka diganti dengan pembelajaran daring yang mengharuskan guru menggunakan berbagai media daring dalam pembelajaran. Media pembelajaran daring yang dibutuhkan guru menggunakan berbagai platform yang berbasis teknologi, sehingga para guru harus mampu menguasai teknologi informasi dan komunikasi. Pada saat ini sangat banyak para guru PAUD kebingungan dalam memanfaatkan media daring berbasis teknologi ini. Akhirnya dengan cara sederhana guru memberikan tugas anak menggunakan aplikasi whatsApp sebagai media pembelajaran daring. Pola komunikasi yang hanya sebatas menggunakan whatsApp memunculkan masalah baru pada orang tua, seperti ketidakmampuan orang tua menerjemahkan pembelajaran untuk anak. Oleh karena itu, pemanfaatan media pembelajaran daring lainnya sangat perlu dikuasai guru. Guru juga dituntut cepat beradaptasi dengan teknologi, agar guru mampu menggunakan beragam aplikasi untuk menunjang pembelajaran daring. 


\section{Metode}

Penelitian ini menggunakan metode studi literature, pengambilan data yang digunakan ialah berdasarkan dari jurnal maupun buku yang sudah dianalisis sehubungan dengan permasalahan yang akan dikaji. Menurut pendapat Sanusi dalam (Wandi, 2019) mengatakan bahwasanya penelitian kepustakaan atau library research ini merupakan kegiatan penelitian yang dilakukan dengan mengumpulkan data-data berdasarkan karya tulis ilmiah yang bertujuan dengan topik penelitian. Pengumpulan data dalam penelitian ini dengan melakukan penelaahan dari bermacam laporan, catatan, jurnal, dan buku yang berkaitan dengan kajian yang akan diteliti (Setiawan, 2017).

Kenapa bisa disebut dengan studi literature, dikarenakan bahan dan datanya yang akan digunakan untuk menjawab permasalahan penelitian ini didapatkan dari studi kepustakaan melalui dokumen, jurnal, majalah, kamus dan buku (Harahap, 2014). Penelitian studi literatur mendapat data dengan cara meneliti dan memahami buku-buku atau sumber lainnya (Sumana, 2014). Dalam mengumpulkan data didasari atas karya tulis ilmiah yang kemudian disesuaikan dengan objek kajian yang akan diteliti, lalu dilaksanakan dengan menelaah, agar terpecahkan permasalahan yang terjadi (Wendy, 2016).

Peneliti menelaah berbagai sumber yang sekiranya berkaitan erat dengan permasalahan kajian dengan mengumpulkan informasi sebanyak mungkin. Sumber kajian peneliti dapatkan dari jurnal maupun buku serta hasil riset peneliti sebelumnya yang sesuai. Tujuan dari penelitian ini ialah guna mengetahui tantangan guru dalam penggunaan media pembelajaran daring dan solusi yang dapat diambil oleh guru.

\section{Hasil Penelitian dan Pembahasan}

Berdasarkan dari berbagai jurnal, buku dan pengamatan penelitian yang sudah ada sebelumnya, maka didapatkan hasil dan pembahasan sebagai berikut :

Pada saat ini sistem pembelajaran diganti dengan pembelajaran jarak jauh atau sering kali disebut pembelajaran daring. Dalam pembelajaran daring sangat dibutuhkan media pembelajaran. Adapun berbagai media daring yang dapat dimanfaatkan guru dalam pembelajaran dimasa pendemi ini menurut Kemndikbud (2020) ialah rumah belajar oleh pusdatin, TV edukasi kemendikbud, ruang guru PAUD, dan sahabat keluarga serta media pembelajaran yang dikelola oleh mitra penyedia teknologi pembelajaran. Selanjutnya dari penelitian Riadil, dkk (2020) mengatakan aplikasi whatsApp juga dapat mendukung pelaksanaan pembelajaran secara daring, karena whatsApp memiliki manfaat pedagogis, social dan teknologi yang dapat menyampaikan pembelajaran, berbagi ide dan berdiskusi secara online.

Atsani (2020) mengatakan dalam penelitiannya bahwa ada beberapa media pembelajaran daring yang dapat digunakan guru seperti whatsApp group, google suite for education, zenius dan aplikasi zoom. Selanjutnya Hartanto, dkk (2020) mengatakan dalam penelitiannya media yang dapat dimanfaatkan guru dalam proses pembelajaran yaitu "MEPETKABA" (Media Pembelajaran TK Berbasis Android). Media ini dibuat dengan mengakomodir kebutuhan dalam pembelajaran daring. Dalam aplikasi ini telah disediakan seluruh bahan dalam pembelajaran, sehingga sangat mudah diakses dan diunduh.

Septiana, dkk (2020) menjelaskan dalam penelitiannya adapun media yang dapat diakses secara online oleh guru yaitu seperti youtube, video, whatsApp, suara dan gambar yang dapat diunduh dari internet. Selanjutnya Susanti (2017) dalam penelitiannya mengatakan bahwa salah satu situs web yang dapat menjadi media dan sumber dalam pembelajaran daring yaitu radioedukasi.kemendikbud.go.id yang telah dikembangkan oleh balai pengembangan media radio pendidikan dan kebudayaan (BPMRPK), kementerian pendidikan dan kebudayaan. Adapun daya kegunaan media audio pendidikan digital melalui situs web BPMRPK ini tergolong baik untuk dipelajari oleh para guru PAUD.

Indiani (2020) dalam penelitiannya menjelaskan media daring sangat membantu guru dalam proses pembelajaran. Begitu banyak media daring yang dapat dimanfaatkan guru dimasa pendemi ini yaitu seperti whatsApp group, google classroom, kelas maya, email, telegram, 
google form dan zoom. Penggunaan media daring sangat penting digunakan dalam proses pembelajaran agar pembelajaran dapat berjalan dengan optimal. Media pembelajaran daring sangat banyak yang dapat dimanfaatkan oleh guru seperti berbagai media daring dari kemendikbud dan media-media daring lainnya.

Seluruh Media pembelajaran daring sangat penting dikuasai oleh guru, namun media yang sangat sering digunakan guru dalam pembelajaran daring yaitu seperti aplikasi whatsApp. Shofa (2020) menjelaskan dalam penelitiannya berbagai media yang digunakan guru untuk saat ini dalam pembelajaran daring yaitu whatsApp group karena melalui aplikasi ini guru dapat mengirim pesan, voice note, berbagai foto, video dan dokumen. Dan aplikasi google classroom juga digunakan guru sebagai media kelas virtual, agar guru dengan mudah menyampaikan materi pembelajaran melalui video. Dwijo, dkk (2020) melakukan penelitian alasan guru menggunakan media whatsApp dalam pembelajaran daring ini, karena aplikasi ini sudah umum dimanfaatkan oleh masyarakat, wali murid juga lebih mudah dalam menggunakan media whatsApp ini dalam berkomunikasi dengan guru.

Selanjutnya Khadijah (2020) mengatakan dalam penelitiannya guru menggunakan aplikasi whatsApp group sebagai wadah untuk berbagi informasi dan sebagai sarana komunikasi. Sejalan dengan hal tersebut Anugrahana (2020) dalam penelitiannya mengatakan terdapat $100 \%$ guru hanya mampu menggunakan whatsApp dalam pembelajaran daring. Alasan guru menggunakan whatsApp yaitu lebih praktis dan lebih mudah dipahami oleh orang tua dan anak.

Selanjutnya Hutami dan Nugraheni (2020) dalam penelitiannya mengatakan bahwa penggunaan whatsApp group pada kegiatan pembelajaran lebih mudah dan flaksibel. Fitur pada whatsApp group dapat digunakan dalam pembelajaran anak PAUD seperti fitur pesan teks, panggilan video dan pesan suara. Sejalan dengan hal tersebut Akollo dan Toisuta (2020) dalam penelitiannya menyebutkan bahwa selama belajar dirumah kegiatan anak dikirim oleh guru melalui whatsApp group. Selanjutnya Botutihe (2020) dalam penelitiannya mengatakan bahwa rata-rata media yang digunakan guru dalam membagi video tutorial kegiatan belajar anak melalui aplikasi whatsApp, karena aplikasi ini banyak digunakan oleh orang tua saat berkomunikasi.

Selanjutnya Ayuni (2020) melakukan penelitian bahwa terdapat salah satu taman kanakkanak membuat pembelajaran daring melalui video tutorial dari kegiatan yang akan dilakukan anak. Video tersebut dibuat sesuai dengan tema-tema dalam pembelajaran. Setelah itu video tutorial tersebut dibagikan guru kepada orang tua atau orang tua langsung yang mengakses melalui youtube. Aplikasi whatsApp group ini juga dapat digunakan guru sebagai media dalam melaksanakan pembelajaran daring serta ada juga beberapa sekolah menggunakan aplikasi zoom sebagai media daring. Setyowahyudi (2020) melakukan penelitian bahwa para guru selama pembelajaran daring menggunakan aplikasi whatsApp sebagai media dan juga dapat menggunakan pembelajaran dari tayangan televisi TVRI. Dalam pembelajaran TVRI anak didampingi orang tua untuk menonton dan menyimak tayangan khusus PAUD. Ketika anak telah selesai menonton tayangan tersebut, lalu guru memberikan kegiatan anak sesuai dengan tayangan yang telah ditonton anak tadi.

Berdasarkan pengamatan dari berbagai penelitian yang sudah ada bahwa guru dalam pembelajaran daring lebih sering menggunakan aplikasi whatsApp sebagai media daring, sebagaimana yang dijelaskan Fitri (2020) dalam penelitiannya whatsApp digunakan untuk menyampaikan informasi proses belajar setiap hari dan melalui aplikasi ini guru mengirim foto kegiatan anak disertai sedikit penjelasan tentang tema yang diajarkan. Dalam pemanfaatan whatsApp juga terdapat kekurangan seperti guru harus menyediakan waktu lebih untuk membalas satu persatu pesan dari orang tua dan komunikasi lisan maupun tulisan terkadang disalah artikan oleh orang tua. Selanjutnya Prajana (2017) dalam penelitiannya mengatakan salah satu aplikasi yang berkembang dan banyak diminati saat ini yaitu whatsApp. Sejalan dengan hal tersebut Rusmiati (2020) mengatakan bahwa whatsApp ialah aplikasi yang memungkinkan guru dengan orang tua berkomunikasi dan saling mengirim pesan tanpa biaya SMS, karena whatsApp menggunakan paket internet. Pembelajaran menggunakan aplikasi 
whatsApp juga terdapat beberapa kendala terkait dengan keterbatasan orang tua maupun jaringan internet yang sulit dijangkau.

Beberapa guru juga menggunakan aplikasi zoom sebagai media. Selanjutnya dalam penelitian Mahayoni (2020) mengatakan proses pembelajaran dapat dilakukan menggunakan aplikasi zoom meeting. Dimana zoom meeting ini merupakan aplikasi komunikasi dengan menggunakan video. Melalui aplikasi ini sebagai media guru dapat menjelaskan materi pada anak dan juga bisa berdiskusi serta Tanya jawab secara langsung dengan anak. Sejalan dengan hal tersebut Rohman dan Rochmawati (2020) mengatakan bahwa zoom merupakan aplikasi pembelajaran daring yang memungkinkan terjadi tatap muka dan komunikasi dengan jarak jauh, sehingga dapat memenuhi kebutuhan belajar anak dimasa usia dini.

Selanjutnya Widiastuti, dkk (2020) mengatakan dalam penelitiannya penerapan $e$ learning berupa google classroom berbentuk tampilan-tampilan tema yang dapat disesuaikan dengan usia perkembangan anak usia dini yang akan membantu proses pembelajaran. Sejalan dengan hal tersebut Shofa (2020) dalam penelitiannya mengatakan bahwa aplikasi google classroom ini membantu guru dan anak untuk saling berinteraksi secara daring. Dalam aplikasi ini guru bisa mengirim tugas, file berupa dokumen, video, foto maupun audio kepada anak. Namun, aplikasi google classroom ini sangat jarang digunakan dilembaga PAUD dalam proses pembelajaran.

Selanjutnya Sari (2020) dalam penelitiannya menjelaskan bahwa aplikasi youtube juga dapat dimanfaatkan oleh guru dalam pembelajaran. Youtube merupakan media dengan layanan video sharing yang dapat berbagi klip video secara gratis. Pemanfaatan aplikasi youtube sebagai media pembelajaran daring sangat diminati anak, karena anak dapat secara langsung melihat guru sebagai tokoh sentral dalam pembelajaran dan video yang ada di youtube juga dapat diputar oleh anak secara berulang-ulang. Sejalan dengan hal tersebut Salehudin (2020) dalam peneltiannya mengatakan bahwa aplikasi youtube berperan sebagai media informasi dan ilmu pengetahuan bagi anak dalam menambah wawasan dan mempermudah tugas yang diberikan guru.

Namun, pada saat ini hanya sedikit guru yang mampu menggunakan aplikasi youtube, zoom, dan google classroom sebagai media dalam pembelajaran daring. Hal ini dikarenakan ada beberapa kendala atau tantangan yang harus dihadapi oleh guru. Sejalan dengan penjelasan Nurdin (2020) dalam penelitiannya bahwa tantangan yang dihadapi guru yaitu kurangnya kemampuan guru dalam mengoperasikan teknologi. Sehingga masih banyak guru PAUD yang belum mahir dalam menggunakan berbagai aplikasi untuk menunjang pembelajaran online. Selanjutnya Srihartini dan Lestari (2020) dalam penelitiannya mengatakan bahwa kendala guru dalam menggunakan teknologi dapat membatasi guru dalam memanfaatkan media daring lainnya. Senada dengan hal tersebut Surahman, dkk (2020) mengatakan dalam penelitiannya bahwa rendahnya kemampuan guru dalam menguasai teknologi yang akan menjadi penghambat guru dalam memperbaharui berbagai media pembelajaran yang sesuai dengan pembelajaran daring saat ini.

Selanjutnya tantangan guru karena kurangnya sarana dan prasarana yang memadai dalam memanfaatkan media pembelajaran daring. Rohman (2019) dalam penelitiannya menyebutkan bahwa ada sebagian besar guru kesulitan untuk menggunakan media daring, hal ini dikarenakan sarana dan prasarana yang masih kurang memadai. Sejalan dengan hal tersebut Satrianingrum (2020) mengatakan dalam penelitiannya berbagai ragam tantangan yang dihadapi guru dalam melaksanakan pembelajaran daring dirumah salah satunya ketersediaan sarana dan prasarana yang kurang memadai, dan perbedaan atmosfir saat belajar dikelas dengan belajar dirumah yang mempengaruhi motivasi anak.

Kemudian tantangan guru ialah terkendala jaringan internet, karena tidak seluruh daerah yang dapat mengkover media daring yang lebih banyak. Ayuni, dkk (2020) dalam penelitiannya mengungkapkan bahwa dalam pembelajaran daring memiliki kendala seperti sulitnya jaringan internet, kuota internet yang memakan biaya cukup besar. Jalal (2020) dalam penelitiannya mengatakan bahwa terdapat $35 \%$ guru yang belum siap dalam menghadapi 
pembelajaran daring karena kurangnya ketersediaan jaringan, dan biaya kuota yang harus dikeluarkan.

Didasarkan hasil penelitian yang dideskripsikan, maka dapat dilihat tantangan guru dalam penggunaan media pembelajaran daring yaitu lemahnya kompetensi yang dimiliki guru dalam menguasai teknologi, kurangnya sarana dan prasarasan dalam memanfaatkan berbagai media pembelajaran daring dan terbatasnya jaringan internet dalam mengkover media pembelajaran daring lainnya.

Tentunya perlu solusi untuk mengatasi masalah ini agar guru PAUD lebih siap menerapkan kegiatan pembelajaran dengan menggunakan media daring. Adapun solusinya yaitu guru sangat perlu belajar lebih banyak lagi melalui pelatihan mengajar efektif, efesien melalui webinar maupun workshop. Widiastuti dkk (2020) mengatakan dalam penelitiannya bahwa telah banyak penawaran tutorial pelatihan untuk guru dalam belajar teknologi. Selanjutnya penelitian Wernely (2018) mengatakan bahwa melalui workshop teknologi dapat meningkatkan kompetensi guru menggunakan teknologi sebagai media dalam pembelajaran daring. Koesdoes, dkk (2020) mengatakan solusi yang dapat diambil dengan cara melatih guru PAUD dalam pembuatan dan penggunaan media pembelajaran multimedia yang mencakup video, animasi, gambar, audio, dan game interaktif. Fasilitas yang memadai juga dapat menjadi solusi bagi guru. astini (2020) dalam penelitiannya mengatakan bahwa kemendikbud juga telah menyediakan platform belajar daring gratis yang bernama "Rumah Belajar" dan platform guru berbagi antar guru dengan nama "Program Guru Berbagi". Serta bagi daerah yang jaringan internetnya lemah guru dapat menggunakan stasiun TVRI dalam belajar untuk anak.

\section{Simpulan dan Saran}

Tantangan guru pada masa pandemic saat ini yaitu guru hanya mampu menggunakan beberapa media dalam pembelajaran daring dari banyaknya media pembelajaran daring. Hasil penelitian berdasarkan temuan terdapat beberapa tantangan guru dalam penggunaan media pembelajaran daring seperti lemahnya kompetensi yang dimiliki oleh guru dalam mengoperasikan teknologi, kurang memadai sarana dan prasarana dalam memanfaatkan media pembelajaran daring dan juga terbatasnya jaringan internet. Adapun solusi yang dapat diambil oleh guru yaitu guru dapat melakukan pelatihan-pelatihan belajar teknologi yang telah disediakan pemerintah secara gratis maupun berbayar. Serta pemerintah juga telah menyediakan program belajar melalui stasiun TVRI dan stasiun televisi Negara lainnya.

Didasarkan hasil penelitian, maka peneliti menyarankan guru dapat menggunakan berbagai media pembelajaran daring dan sekolah dapat memenuhi fasilitas-fasilitas yang dapat menunjang kemampuan guru dalam mengoperasikan teknologi saat pembelajaran. Agar pembelajaran daring ini menyenagkan bagi anak

\section{Daftar Rujukan}

Adisel dan Prananosa, Ahmad Gawdy. (2020). Penggunaan Teknologi dan Komunikasi dalam Sistem Manajemen Pembelajaran pada Masa Pandemi Covid 19. Journal of Administrasi and Educational Management. Volume 3. Nomor 1

Adlin. (2019). Analisis Kemampuan Guru dalam Memanfaatkan Media Berbasis Komputer pada Pembelajaran di Sekolah Dasar. Jurnal Imajinasi. Volume 3. Nomor 2

Afrianti, Y., \& Wirman, A. (2020). Penggunaan Media Busy Book Untuk Menstmulasi Kemampuan Membaca Anak. Jurnal Pendidikan Tambusai, 4(2), 1156-1163.

Ahmad, D. S., \& Wirman, A. (2020). Penggunaan Media Youtube Kids untuk Pengembangan Kemampuan Menyimak Anak Usia 5-6 Tahun. JFACE: Journal of Family, Adult, and Early Childhood Education, 2(4), 311-319.

Ahmad. (2020). Peningkatan Pedagogik Guru dalam Pembelajaran Jarak Jauh Melalui Pendampingan Sistem Daring, Luring, atau Kombinasi pada Masa New Normal Covid 19. Jurnal Paedagogy: Jurnal Penelitian dan Pengembangan Pendidikan. Vol 7. No 4 
Akollo, Jane Gresia. (2020). Keterlibatan Orang Tua dalam Pembelajaran Anak Usia Dini Selama Belajar Dari Rumah di Masa Pandemi COVID-19. Jurnal Pendidikan Agama Kristen. Vol 6. No 2

Anggraeni, Anastasia Dewi. (2017). Kompetensi Kepribadian Guru membentuk Kemandirian Anak Usia Dini. Jurnal Pendidikan Anak. Vol 3. No 2

Anugrahana, Andri. (2020). Hambatan, Solusi dan Harapan : Pembelajaran Daring Selama Masa Pandemi COVID-19 Oleh Guru Sekolah Dasar. Jurnal Pendidikan dan Kebudayaan. Vol 10. No 3

Ariyanti, Tatik. (2016). Pentingnya Pendidikan Anak Usia Dini bagi Tumbuh Kembang Anak. Jurnal Dinamika Pendidikan Dasar. Vol 8. No 1

Ashsiddiqi, M Hasbi. (2012). Kompetensi Sosial Guru dalam Pembelajaran dan Pengembangannya. Jurnal TA'DIB. Vol 17. No 1

Astini, Ni Komang Suni. (2020). Pemanfaatan Teknologi Informasi dalam Pembelajaran Tingkat Sekolah Dasar pada masa Pandemi COVID-19. Jurnal Lampuhyang. Vol 11. No 2

Atsani, KH Lalu Gede Muhammad Zainuddin. (2020). Transformasi Media Pembelajaran pada Masa Pandemi Covid-19. Jurnal Studi Islam. Volume 1. Nomor 1

Ayuni, Despa, dkk. (2020). Kesiapan Guru TK Menghadapi Pembelajaran Daring Masa Pandemi Covid 19. Jurnal Obsesi : Jurnal Pendidikan Anak Usia Dini. Vol 5. No 1

Botutihe, Sukma Nurilawati, dkk. (2020). Strategi Pembelajaran Physical Distancing Guru PAUD dalam Menghadapi Pandemi COVID-19. Jurnal Obsesi : Jurnal Pendidikan Anak Usia Dini. Vol 5. No 2

Dwijo, Al-Qudus Nofiandri Eko Sucipto, dkk. (2020). Penerapan Metode Pembelajaran Melalui Media WhatsApp selama Pandemi COVID-19 di RA Al-Qodir. Journal of Early Childhood Education and Development. Vol 2. No 2

Elfahmi, Roni. (2020). Upaya Peningkatan Kompetensi Guru dalam Menerapkan Pembelajaran Daring Masa Pandemi Covid 19 di SMA Negeri 3 Seunagan. Jurnal Bionatural. Vol 7. No 2

Fitri, Nur Lailatul. (2019). Pemanfaatan Grup WhatsApp Sebagai Media Informasi Proses Belajar Anak Di KB Permata Bunda. Jurnal Al Hikmah : Indonesian Journal Of Early Childhood Islamic Education. Vol 3. No 2

Handarini, Oktafia Ika. (2020). Pembelajaran Daring Sebagai Upaya Study From Home (SFH) Selama Pandemi COVID-19. Jurnal Pendidikan Administrasi Perkantoran. Vol 8. No 3

Harahap, Nursapia. (2014). Penelitian Kepustakaan. Jurnal Iqra'. volume 8 No

Harmani, Sri. (2020). Efektivitas Pembelajaran Daring di Masa Pandemi Covid 19.Diperolehdarihttp://bdkjakarta.kemenag.go.id/berita/efektivitas-pembelajaran-daringdi-masa-pandemi-covid-19

Hartanto, Supri, dkk. (2020). MEPETKABA Sebagai Alternatif Pembelajaran di Masa Pandemi. Jurnal UPMK. Vol 5. No 1

Hidayat, Wahyu Diantoro. 2018. Kompetensi Pedagogik Guru Dalam Menggunakan Media Pembelajaran di Madrasah Ibtidaiyah (Studi Kasus di MIN Jejeran). Jurnal Ulumuddin. Vol 8. No

Husain, Rusmin dan Kaharu, Anton. (2020). Menghadapi Era Abad 21 : Tantangan Guru Pendidikan Anak Usia Dini di Kabupaten Bone Bolango. Jurnal Obsesi : Jurnal Pendidikan Anak Usia Dini. Volume 5. Nomor 1

Hutami, Meyda Setyana dan Nugraheni, Aninditya Sri. (2020). Metode Pembelajaran Melalui WhatsApp Group Sebagai Antisipasi Penyebaran COVID-19 Pada Anak Usia Dini di TK ABA Kleco Kotagede. Jurnal PAUDIA. Vol 9. No 1

Indiani, Baroroh. (2020). Mengoptimalkan Proses Pembelajaran Dengan Media Daring Pada Masa Pandemi COVID-19. Jurnal Sipatokkong BPSDM. Vol 1. No 3

Indyati, F., Suryana, D., \& Wirman, A. (2020). Pengaruh Pembelajaran Metode Montessori terhadap Pendidikan Agama Islam Anak Usia Dini. Jurnal Pendidikan Tambusai, 4(3), 3267-3280. 
Jalal, Muhaiminah. (2020). Kesiapan Guru Menghadapi Pembelajaran Jarak Jauh dimasa COVID-19. Jurnal Pendidikan Islam Anak Usia Dini. Vol 2. No 1

Khadijah, dan Gusman, Media. (2020). Pola Kerja Sama Guru Dan Orang Tua Mengelola Bermain Anak Usia Dini Selama Masa Pandemi COVID-19. Jurnal Kumara Cendikia. Vol 8. No 2

Koedoes, Yuni Aryani, dkk. (2020). Solusi Pembelajaran Anak Usia Dini Pada Masa Pndemi COVID-19. Jurnal Pengabdian Masyarakat Ilmu Terapan. Vol 2. No 2

Lasaiba, Djamila. (2016). Pola Pengembangan Model Pembelajaran Pendidikan Anak Usia Dini. Jurnal Fikratuna. Vol 8. No 2

Latief, dkk. (2013). Orientasi Baru Pendidikan Anak Usia Dini. Kencana : Pranada Media Group

Lisnawati, Yesi. (2015). Konsep Khalifah Dalam Al-Quran Dan Implikasinya Terhadap Tujuan Pendidikan Islam. Skripsi. Diterbitkan. Universitas Pendidikan Indonesia

Madyawati, Lilies. (2010). Strategi Pengembangan Bahasa pada Anak. Jakarta: Prenada Media.

Mahayoni, Ni Made Sri. (2020). Penggunaan Aplikasi Zoom Meeting Pada Pembelajaran Agama Hindu di Masa Pandemi. Jurnal Widya Sastra Pendidikan Agama Hindu. Vol 3. No 1

Melfianora. (2019). Penulisan Karya Tulis Ilmiah Dengan Studi Literatur. Pekanbaru

Mirzaqon, T A dan Purwoko, Budi. (2017). Studi Kepustakaan Mengenai Landasan Teori dan Praktik Konseling Expressive Writting. Jurnal BK Unesa. Vol 8. No 1

Mulyasa. (2012). Manajemen PAUD. Bandung : PT Remaja Rosdakarya.

Nasir, dkk. (2020). Memaksimalkan Fitur "Breaking Rooms" Zoom Meeting pada Pendidikan Anak Usia Dini dimasa Pandemi COVID-19. Jurnal Obsesi : Jurnal Pendidikan Anak Usia Dini. Vol 5. No 1

Novita, S., Yetti, R., \& Wirman, A. (2019). Pengaruh Penggunaan Media Diorama terhadap Kemampuan Bercerita di Taman Kanak-Kanak. JFACE: Journal of Family, Adult, and Early Childhood Education, 1(1), 53-62.

Nurdin dan La Ode Anhusadar. (2020). Efektivitas Pembelajaran Online Pendidik PAUD di Tengah Pandemi Covid 19. Jurnal Obsesi : Jurnal Pendidikan Anak Usia Dini. Vol 5. No 1

Nuriansyah, Fazar. (2020). Efektifitas Penggunaan Media Online dalam Meningkatkan Hasil Belajar pada Mahasiswa Pendidikan Ekonomi saat awal Pandemi Covid 19. Jurnal pendidikan Ekonomi Indonesia. Volume 1. Nomor 2

Prajana, Andika. (2017). Pemanfaatan Aplikasi WhatsApp Dalam Media Pembelajaran di UIN AR-RANIRY BANDA ACEH. Jurnal Pendidikan Teknologi Informasi. Vol 1. No 2

Pramana, Cipta. (2020). Pembelajaran Pendidikan Anak Usia Dini (PAUD) di Masa Pandemi Covid 19. Jurnal Dunia Anak Usia Dini. Vol 2. No 2

Putra, San, dkk. (2020). Kompetensi Kepribadian Guru dengan Disiplin Belajar Anak Usia Dini Selama Corona Visus Disease 19. Jurnal Edu Riligia. Volume 4. Nomor 2

Putranti, Nurita. (2013). Cara Membuat Media Pembelajaran Online Menggunakan Edmodo. Jurnal Pendidikan Informatika dan Sains. Vol 2. No 2

Putria, Hilna, dkk. (2020). Analisis Proses Pembelajaran Dalam Jaringan(Daring) Masa Pandemi Covid 19 Pada Guru Sekolah Dasar. Jurnal Basicedu. Vol 4. No 4

Riadil, Ikrar Genidal, dkk. (2020). Persepsi Guru PAUD Terhadap Sistem Pembelajaran Daring Melalui WhatsApp di Masa Pandemi COVID-19. Jurnal PAUDIA. Vol 9. No 2

Rohman, Abdul dan Rochmawati, Nur Intan. (2020). Pemanfaatan Aplikasi Zoom dan Google Meet Untuk Pembelajaran Daring di TK Pembina ABA 54 Dan KB Aisyiyah 18 Semarang. Jurnal Prodi Teknik Informatika UNW. Vol II. No 2

Rohman, M. Ghofar dan Susilo, Hadi Purnomo. (2019). Peran Guru dalam Penggunaan Media Pembelajaran Berbasis Teknologi Informasi dan Komunikasi(TIK) Studi Kasus di TK Muslimat Nu Maslakul Huda. Jurnal Pendidikan dan Pembelajaran. Vol 8. No 1 
Rusmiati. (2020). Pembelajaran Menggunakan Aplikasi Media Sosial WhatsApp Untuk Anak Usia Dini pada Kelompok A di BA AT-Tauhid Pagelarang Kemranjen. Skripsi. Diterbitkan. Institut Agama Islam Negeri Puwokerto

Salehudin, Mohammad. (2020). Literasi Digital Media Sosial Youtube Anak Usia Dini. Jurnal Ilmiah Potensia. Vol 5. No 2

Salsabila, Unik Hanifah, dkk. (2021). Pengaruh Penggunaan Media Belajar Online Selama Pandemi. Jurnal Ilmiah Wahana Pendidikan. Vol 7. No 1

Sari, I. M., \& Wirman, A. (2019). Metode Wafa dalam Pembelajaran Al-qur'an di Sekolah Alam TKIT Ar-Royyan Pegambiran, Padang. Indonesian Journal of Islamic Early Childhood Education, 4(1), 69-78.

Sari, Lurita. (2020). Upaya Menaikkan Kualitas Pendidikan Dengan Pemanfaatan Youtube Sebagai Media Ajar Pada Masa Pandemi COVID-19. Jurnal Tawadhu. Vol 4. No 1

Satrianingrum, Arifah Prima dan Prasetyo, Lis. (2020). Persepsi Guru Dampak Pandemi Covid19 Terhadap Pelaksanaan Pembelajaran Daring di PAUD. Jurnal Obsesi : Jurnal Pendidikan Anak Usia Dini. Vol 5. No 1

Sebayang, F Ari Anggraini, dkk. (2020). Pemanfaatan Media Pembelajaran Online untuk Meningkatkan Pembelajaran Mandiri di Masa New Normal. Jurnal Pelita Masyarakat. Vol 2. No 1

Septiana, Ika, dkk. (2020). Aspek Kebahasaan Media Digital Pada Pembelajaran Anak Usia Dini dimasa Pandemi COVID-19. Internasional Proceeding of Innovative and Thasdiseiplinary Studies (IPISTRANS).

Shofa, Mila Faila. (2020). Inovasi Pembelajaran Pada Pendidikan Anak Usia Dini di Masa Pandemi COVID-19. Jurnal Buana Gender. Vol 5. No 2

Srihartini, Yusi dan Lestari, Maulidia Pratami. (2020). Pembelajaran Pendidikan Anak Usia Dini Online di Era Pandemi COVID-19. Journal Of Islamic Education. Vol 1. No 2

Styowahyudi, Rendy dan Ferdiyanti, Tiara. (2020). Keterampilan Guru PAUD Kabupaten Ponorogo Dalam Memberikan Penguatan Selama Masa Pandemi COVID-19. Jurnal Golden Age. Vol 4. No 1

Subhi, Imam. (2020). Urgensi Kompetensi Guru Dalam Pembelajaran Online di Masa Pandemi Covid 19. Jurnal Integensia. Vol 8. No 1

Sudrajat, Jajat. (2020). Kompetensi Guru di Masa Pandemi Covid-19. Jurnal Riset Ekonomi dan Bisnis. Vol 13. No 1

Suhendro, Eko. (2020). Strategi Pembelajaran Pendidikan Anak Usia Dini dimasa Pandemi Covid 19. jurnal Ilmiah Tumbuh Kembang Anak Usia Dini. Vol 5. No 3

Sum, Theresia Alviani dan Emilia Graciela Mega Taran. (2020). Kompetensi Pedagogik Guru Pendidikan Anak Usia Dini dalam Perencanaan dan Pelaksanaan Pembelajaran. Jurnal Obsesi : Jurnal Pendidikan Anak Usia Dini. Vol 4. No 2

Sum, Theresia Alviani. (2019). Kompetensi Guru Pendidikan Anak Usia Dini Dalam Pembelajaran di PAUD di Kecamatan Langke Rembong Kabupaten Manggarai. Jurnal Lonto Leok Pendidikan Anak Usia Dini. Vol 2. No 1

Sumarna. (2014). Konsep Guru Dalam Pandangan Ki Hajar Dewantara Dilihat Dari Perspektif Pendidikan Islam. Universitas pendidikan indonesia. Respitori. Upi.edu.

Surhaman, Eva, dkk. (2020). Tantangan Pembelajaran Daring di Indonesia. Journal of Islamic Education Management. Vol 5. No 2

Suryana, Dadan. (2013). Pendidikan Anak Usia Dini. Padang : UNP Press. (2016). Stimulasi dan Aspek Perkembangan Anak. Jakarta : Kencana.

Suryani, M., \& Wirman, A. (2019). PENINGKATAN KEMAMPUAN ANAK MENGENAL HURUF HIJAIYAH MELALUI MEDIA PUZZLE STYROFOAM MODIFIKASI DI TAMAN KANAK-KANAK ISLAM YANNIRA PADANG. Jurnal Pendidikan Tambusai, 3(3), 1646-1651.

Susanti, Mariana. (2017). Daya Guna Media Audio Pendidikan Digital Melalui Situs Web. Jurnal IPTEK-KOM. Vol 19. No 1

Suyadi. (2010). Psikologi Belajar PAUD. Yogyakarta : Pedagogia. 
(2014). Teori Pembelajaran Anak Usia Dini. Bandung : Remaja Rosdakarya

Wahyono, Pancojari dan Husamah, H. (2020). Guru profesional di masa pandemi COVID-19: Review implementasi, tantangan, dan solusi pembelajaran daring. Jurnal Pendidikan Profesi Guru. Vol 1. No 1

Wandi, Zherly Nadia. (2019). Analisis Kemampuan Motorik Halus dan Kreativitas pada Anak Usia Dini melalui Kegiatan Kolase. Jurnal Obsesi : Jurnal Pendidikan Anak Usia Dini. Vol 4. No 1

Warnely. (2018). Upaya Peningkatan Kemampuan Guru dalam Penggunaan Teknologi Informasi dan Komunikasi (TIK) di TK Aisyiyah Kota Dumai. Jurnal Pendidikan dan Pengajaran. Vol 2. No 3

Widiastuti, Yuanita Kristiani Wahyu, dkk. (2020). Mengkaji Penerapan E-Learning Pada Anak Usia Dini. Jurnal Obsesi : Jurnal Pendidikan Anak Usia Dini. Vol 5. № 2

Windarto, Agus Perdana. (2019). Pelatihan Guru-guru PAUD Melek Teknologi Kabupaten Simalungun. Jurnal Ilmiah Pengabdian Kepada Masyarakat. Vol 1. No 1

Wirman, A., Yaswinda, Y., \& Tanjung, A. (2018). Pengunaan Media Moving Flahscard untuk Stimulasi Kemampuan Literasi Anak Usia Dini. Early Childhood: Jurnal Pendidikan, $2(2 b), 54-62$

Wulandari, Hesti dan Purwanta, Edi. (2020). Pencapaian Perkembangan Anak Usia Dini di TK selama Pembelajaran Daring saat Pandemi Covid-19. Jurnal Obsesi : Jurnal Pendidikan Anak Usia Dini. Vol 5. No 1

Yamin, Martinis dan Jamilah Sabri Sanan. (2012). Panduan PAUD Pendidikan Anak Usia Dini. Jakarta : Gaung Persada Press Group.

Yanti, R., \& Wirman, A. (2020). Peningkatan Kemampuan Anak Mengenal Bentuk Geometri Melalui Media Balok di TK Ar-Raudah Padang. Jurnal Halaqah, 2(3), 323-330.

Yaumi, Muhammad. (2013). Prinsip-prinsip Desain Pembelajaran. Jakarta : Kencana

Yulsyofriend. (2013). Bahan Ajar Bahasa Anak Usia Dini. Padang : UNP Press.

Yusrizal, dkk. (2017). Kompetensi Guru dalam Memanfaatkan Media Pembelajaran Berbasis Teknologi Informasi dan Komunikasi (TIK) di SD Negeri 16 Banda Aceh. Jurnal Ilmiah Pendidikan Guru Sekolah Dasar. Vol 2. No 2

Zaenab, Siti. (2015). Profesionalisme Guru PAUD menuju NTB bersaing. Yogyakarta : Deepublish 